\title{
Medium Density Fiberboards from Date Palm Residues a Strategic Industry in the Arab World
}

\author{
Hamed El-Mously ${ }^{1, a}{ }^{*}$, M.Saber ${ }^{2}$ \\ ${ }^{1}$ Faculty of Engineering, Ain Shams University, 1 Elsarayat St., Abbaseya, 11517, Cairo, Egypt \\ ${ }^{2}$ Expert in economy and project feasibility studies, Cairo, Egypt \\ âHamed.elmously@gmail.com
}

Keywords: wood availability, date palm products of pruning, medium density fiber boards

\begin{abstract}
The success of the environmental movements world-wide has led to the decrease of wood availability in the world market, and hence to the soaring of wood prices .This in turn has led to the increase of the burden on the balance of payment of the Arab countries, relying on the importation of wood to satisfy the needs of their populations in shelter, furniture, etc. Meanwhile, the Arab World includes the palm belt extending from Morocco in the far West to Iraq in the Far East. Therefore, it makes sense to look to the date palm residues, mainly resulting from the palm pruning, as a sustainable renewable material base to locally manufacture wood substitutes as, for the example, the composite panels including the medium density fiber boards (MDF), particle boards, block boards, etc. Within a research project, conducted by the Faculty of Engineering, Ain Shams University with the collaboration of the ministry of environment, samples of the date palm secondary products have been collected in proportion with the available products of palm pruning (palm midribs, leaflets, spadix stems and coir), threshed and sent to the laboratory of Deshna MDF factory in Kena governorate .The result of tests confirm that the MDF samples, manufactured from the date palm secondary products, satisfy the mechanical and physical requirements of international standards of MDF. A technical and economic feasibility study has been conducted on a suggested industrial project to manufacture MDF boards in ELBahariah oases. The results of this study show that the profitability indicators of this project are high: the return rate on invested capital is $(39.4 \%)$, the revenue to cost rate is $(1.43: 1)$, the payback period is 3.6 years and the internal rate of return is $36.2 \%$.
\end{abstract}

\section{Introduction}

The success of the environmental movements world-wide has led to the decrease of wood availability in the international market. This has led to the soaring of wood prices, which has increased the burden on the balance of payments in the Arab countries, relying basically on importation to satisfy people's need, of wood for shelter, furniture, etc. Meanwhile, the Arab countries are distinguished with the date palm belt extending from Morocco in the West to Iraq in the East including 102.4 million palms [5]. Thus, it is logic to look to the products of pruning of date palm as a renewable and sustainable resource for the manufacture of wood substitutes, such as the medium density fiberboards (MDF), particle boards (pb), blockboards, etc.

\section{Present Status of Wood Market: A Case Study from Egypt}

Fig. 1 illustrates the value of Egypt's wood imports until 2011 [8]. It is clear that beginning from 2000 the value of wood imports is steadily ascending reaching $~ 2.5$ billion US\$ in 2011. Fig. 2 [10] illustrates the change of value of Egypt's wood imports during the period from 2000 to 
2016. It is noteworthy that the increase of the financial burden of wood imports is tremendous, especially as weighed by the local currency. As is clear from this figure, the value of wood imports has doubled over the ten years from 2005 to 2015 and the average rate of growth in Egypt's imports of wood during this period was about $6.8 \%$ annually. This represents a huge burden on the shoulders of the furniture manufactures, as well as the consumers leading to the collapse of furniture industry in Egypt and the tendency of the consumers to rely on imported furniture probably coming from china. Fig. 3 [7] represents a five-year forecast of Egypt's wood sector under a 6 percent GDP growth rate. It is clear from this figure that both the low and high endforecasts show a tremendous increase of the value of wood imports, representing a huge burden on the balance of payments of Egypt. Fig. 4 [11-20] illustrates the change of prices of wood species, as well as wood products due to the big devaluation of the Egyptian pound in November 2016. This has had a drastic influence on the small-scale furniture establishments, leading to the closure of many of them.

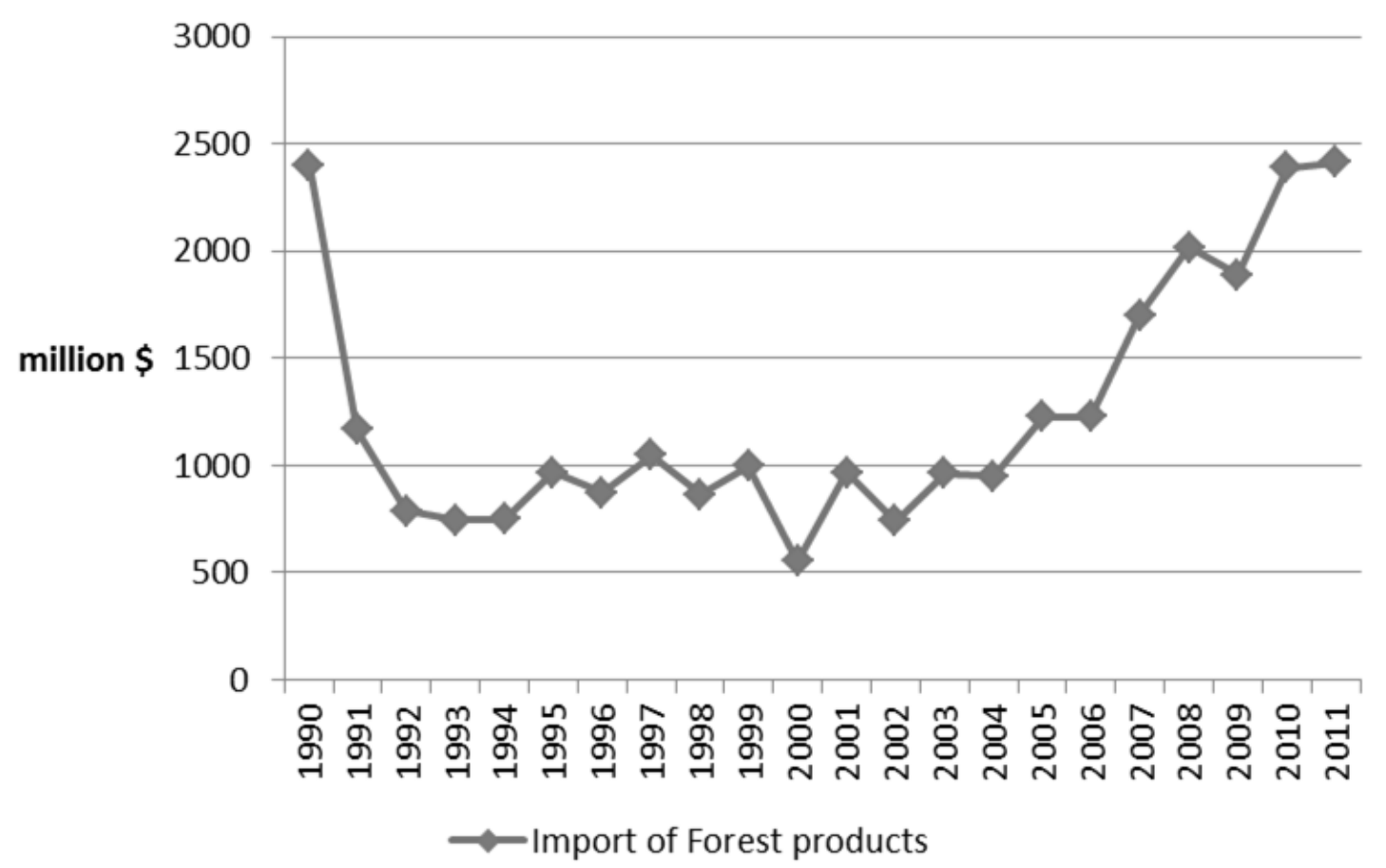

Fig. 1: The value of Egypt's wood imports until 2011 [8]. 


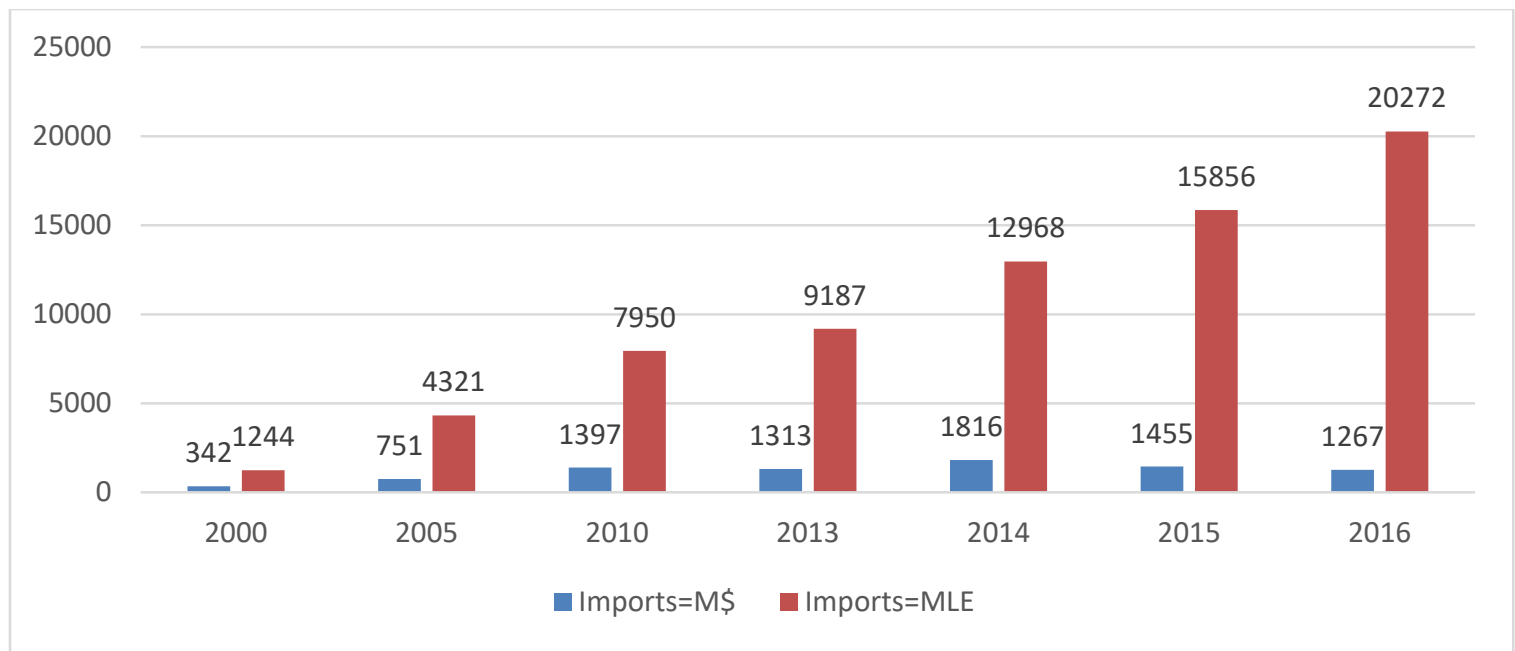

Fig. 2: The value of Egypt's imports of wood in US dollars and the equivalent value in local currency [10].

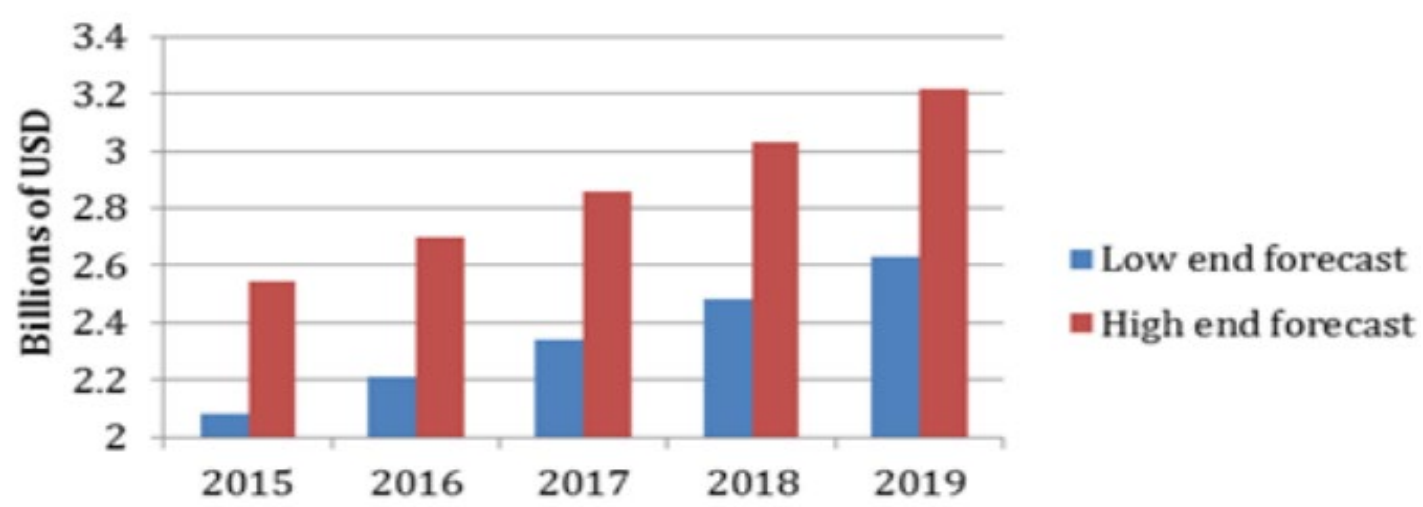

Fig. 3: Five-Year forecast of Egypt's wood sector value under a 6 percent GDP Growth Rate [7].
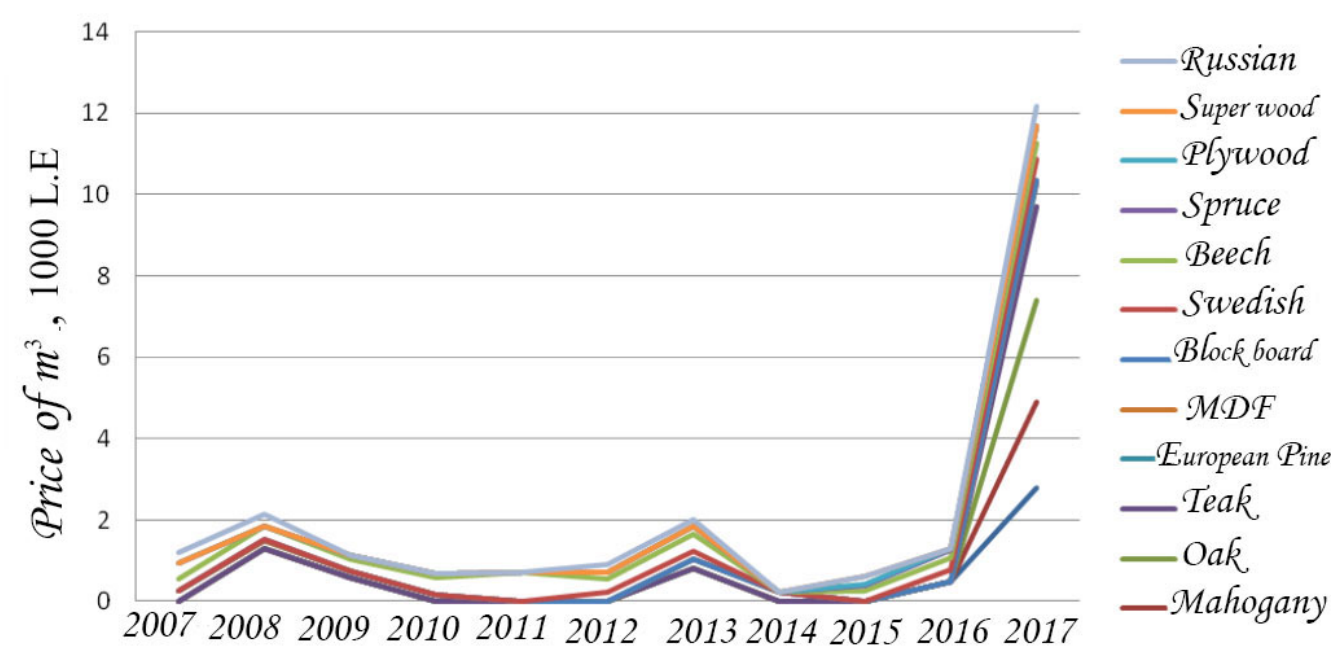

Fig. 4: Change of value of prices of wood species and wood products during the period from 2007 to 2017 [11-20]. 


\section{Strategic Necessity of Reliance on Agricultural Residues as a Substitute for Imported Wood}

Fig. 5 illustrates the value of Egypt imports of wood and wooden products during the period from 2010 to 2014 [6]. It is clear from this figure that the value of Egypt's imports in 2014 is approaching $\cong 2$ billion US \$. Assuming the same previous average rate of wood imports (6.8\%), the future estimates suggest that the cost of imports of wood and wood products will exceed $\sim 22.8$ billion US $\$$ in 2050! This represents an unacceptable burden on the future generations. Thus, there is a strategic necessity to rely on the agricultural lignocellulosic residues (ALR) as an alternative to imported wood. The annual amounts of these ALR amount to about 80 million tons (oven dry weight): $\sim 76$ million field crops residues and $\sim 4$ million products of pruning of fruit trees [1]. The industrial utilization of ALR will lead to the building of endogenous scientific and technological capacities, as well as the rising of successive waves of innovation beginning from rural areas and reaching urban areas in the country.

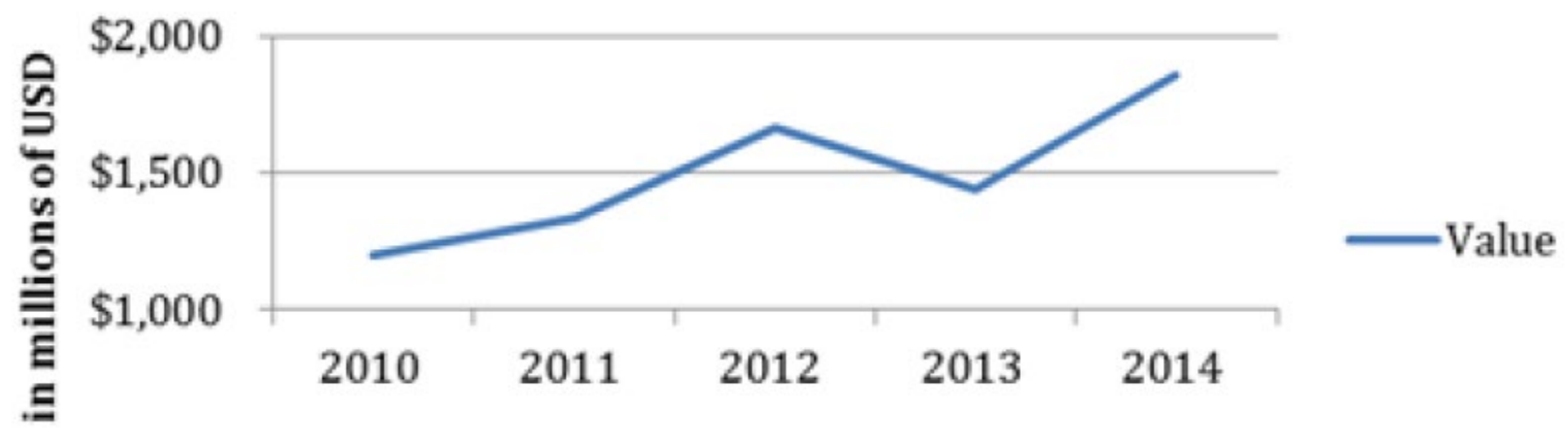

Fig. 5: The value of Egypt imports of wood and wooden products during the period from 2010 to $2014[6]$.

\section{The Medium Density Fiber Board Industry in the World: Present Status and Future Prospects}

The medium density fiber boards (MDF) are classified among the lignocellulosic composite panels. This industry relies basically on wood resources. There is a growing trend at the present time to utilize the agricultural residues as an alternative to wood in view of the environmental concerns of cutting of wood trees in forests, as well as the increase of wood demand for the MDF products.

The MDF industry came to existence during the ends of the sixties of the last century and witnessed a considerable growth during the seventies and eighties of that century. The MDF industry in Egypt has begun by the establishment of Naga-Hammady Fiberboard Company in 2001. This is the sole company in Egypt producing MDF boards from bagasse. The bagasse is one of the first ALR to be used in particle board production since the First World War. Then it was used in pulp production. Afterwards other ALR were used for the production of MDF, such as cotton stalks, wheat straw, maise stalks, rice straw, rice husk and palm midribs.

The MDF boards are distinguished with acceptable mechanical and physical properties. That is why MDF products found wide applications in indoor use (e.g. furniture and flooring) and outdoor use. The international statistics (Fig.6) illustrate the progressive increase of the production capacities of MDFduring the period from 2007 to 2017 reaching 100 million $\mathrm{m}^{3}$ [9]. 


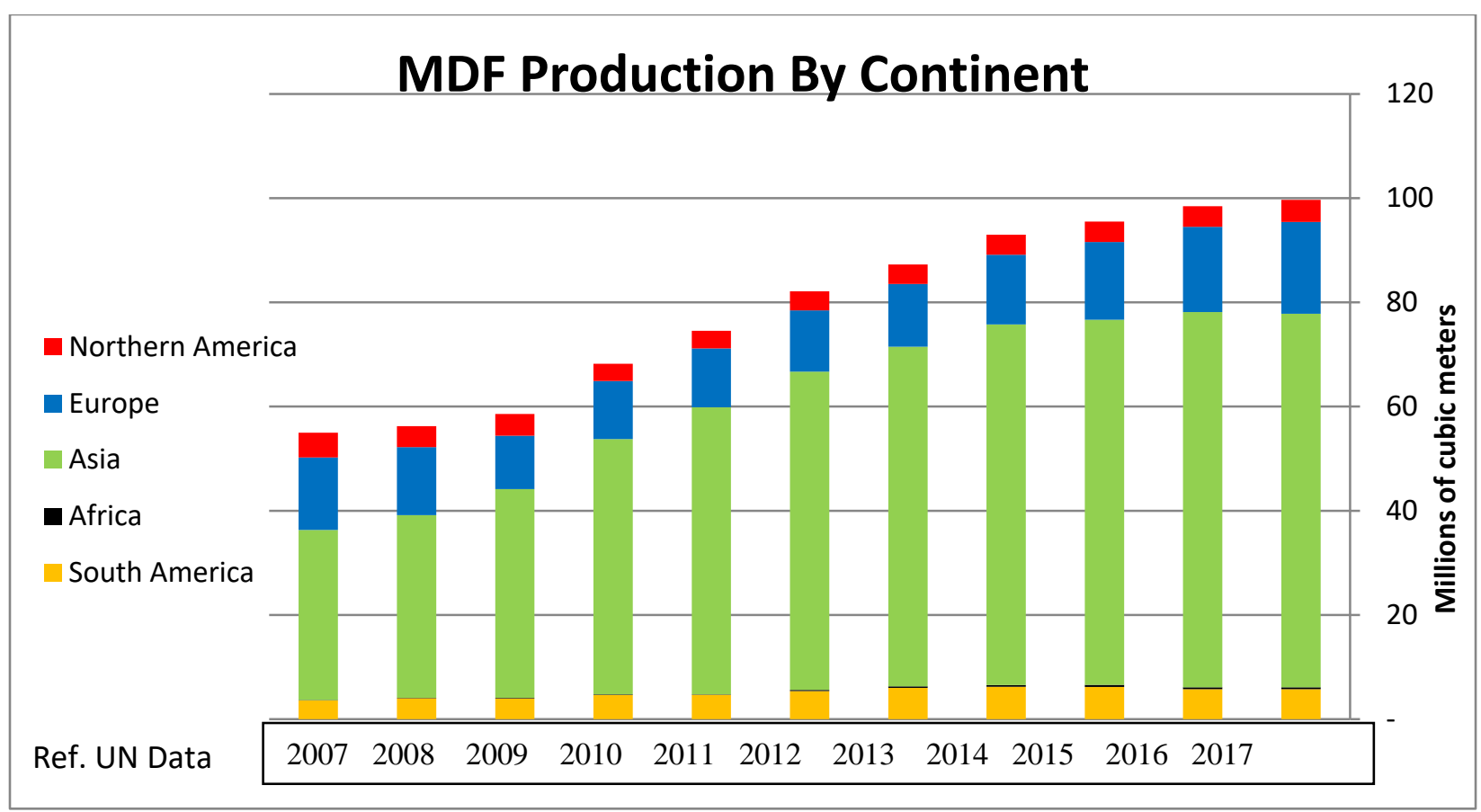

Fig. 6: The progressive increase of the production capacities of MDF [9].

\section{MDF from Date Palm Products of Pruning}

\section{The Date Palm: An Essential Component of the Flora in Egypt}

Table (1) illustrates an estimation of the number of palms in Egypt in 2015. It is clear from this table that Egypt possesses $\sim 15$ million productive palms, distributed among Egypt's 28 governorates. Proceeding from the data of this table the following governorates may be considered leading in palm plantations: Aswan, Giza, Beheira, New Valley and Sharkia.

\begin{tabular}{cccc}
\hline $\mathbf{N}$ & Governorates & $\begin{array}{c}\text { Number of Palms } \\
\text { (million) }\end{array}$ & Order \\
\hline $\mathbf{1}$ & Aswan & 2.48 & First \\
\hline $\mathbf{2}$ & Giza & 1.81 & Second \\
\hline $\mathbf{3}$ & Beheira & 1.37 & Third \\
\hline $\mathbf{4}$ & NewValley & 1.26 & Fourth \\
\hline $\mathbf{5}$ & Sharkia & 1.21 & Fifth \\
\hline
\end{tabular}


Table 1: The number of palms in Egypt in 2015 [4]

\begin{tabular}{|c|c|c|c|c|}
\hline Governorates & Area & $\begin{array}{l}\text { fruitful palm } \\
\text { (palm) }\end{array}$ & $\begin{array}{l}\text { Productivity } \\
\text { (Kg\palm) }\end{array}$ & $\begin{array}{l}\text { Production } \\
\text { (ton) }\end{array}$ \\
\hline Alexandria & 436 & 82563 & 83.706 & 6911 \\
\hline Beheira & 14327 & 1371794 & 168.436 & 231060 \\
\hline Garbiya & 315 & 48368 & 103.560 & 5009 \\
\hline Kafr El Sheikh & 5159 & 343427 & 128.062 & 43980 \\
\hline Dekhalia & 674 & 216716 & 110.010 & 32841 \\
\hline Damiatta & 15 & 866216 & 99.166 & 85899 \\
\hline Sharkia & 260 & 1211196 & 171.536 & 207764 \\
\hline Ismailia & 1327 & 670532 & 131.809 & 88382 \\
\hline port said & - & 11195 & 84.413 & 945 \\
\hline Elsuez & 456 & 93879 & 94.590 & 8880 \\
\hline Monofia & 75 & 163339 & 100.656 & 16441 \\
\hline Qalyubia & 547 & 203469 & 125.729 & 25582 \\
\hline Cairo & 810 & 37586 & 53.424 & 2008 \\
\hline $\begin{array}{c}\text { Lower } \\
\text { Egypt(Total) }\end{array}$ & 24392 & 5320280 & 140.350 & 746702 \\
\hline Giza & 21089 & 1813322 & 130.798 & 237178 \\
\hline BeniSuef & 61 & 320783 & 92.324 & 29616 \\
\hline Faiyum & 1158 & 643074 & 133.832 & 86046 \\
\hline Minya & 586 & 337608 & 110.000 & 37137 \\
\hline $\begin{array}{l}\text { Middle Egypt } \\
\text { (Total) }\end{array}$ & 22894 & 3114787 & 125.208 & 389995 \\
\hline Asyut & 400 & 462501 & 95.431 & 44137 \\
\hline Sohag & 799 & 414071 & 93.291 & 38713 \\
\hline Qena & 1039 & 361346 & 61.368 & 22175 \\
\hline Luxor & 552 & 192360 & 70.254 & 13514 \\
\hline Aswan & 24840 & 2477458 & 90.840 & 225054 \\
\hline $\begin{array}{l}\text { Upper Egypt } \\
\text { (Total) }\end{array}$ & 27630 & 3908663 & 87.906 & 343593 \\
\hline $\begin{array}{c}\text { Inside } \\
\text { Valley(Total) }\end{array}$ & 74916 & 12343730 & 119.922 & 1480290 \\
\hline New Valley & 18482 & 1262475 & 81.681 & 103120 \\
\hline Matruh & 7207 & 330674 & 90.001 & 29761 \\
\hline Red Sea & 134 & 39528 & 42.856 & 1694 \\
\hline North Sinai & 9076 & 320650 & 53.429 & 17132 \\
\hline South Sinai & - & 91304 & 39.998 & 3652 \\
\hline Nubariya & 5795 & 567970 & 86.744 & 49268 \\
\hline $\begin{array}{l}\text { Outside Valley } \\
\text { (Total) }\end{array}$ & 40694 & 2612601 & 78.323 & 204627 \\
\hline Total & 115610 & 14956331 & 112.656 & 1684917 \\
\hline
\end{tabular}


Evaluation of the Available Quantities of Products of Prunning: A Case Study from ElBahariah Oases

Within the framework of the Project of Care of Date Palm in El-Bahariah oases [3], the mass of the products of pruning has been determined for the Siwi, Freihi and Gaga palm species. Taking as an example the Siwi species (a dominant species in Egypt), it is possible to give the following estimations for the annual products of pruning of one palm.

\begin{tabular}{lcc}
\hline $\mathbf{N}$ & Secondary products & $\begin{array}{c}\text { Mass per palm kg (air } \\
\text { dry weight) }\end{array}$ \\
\hline $\mathbf{1}$ & Palm midribs & 15 \\
\hline $\mathbf{2}$ & Palm leaflets & 14.6 \\
\hline $\mathbf{3}$ & Spadix stems & 9 \\
\hline $\mathbf{4}$ & Coir & 1.56 \\
\hline $\mathbf{5}$ & Midrib end & 14 \\
\hline Total & & $54.2 \mathrm{~kg}$ \\
\hline
\end{tabular}

Taking the Siwi palm as a basis for estimation, the total annual available mass of the products of pruning of date palm in Egypt amounts to 810,000 tons, which represents a considerable sustainable material base for the establishment of a wide spectrum of industrial activities.

\section{Study of the Technical and Economic Feasibility of Manufacture of MDF from the Products of Pruning of Date Palms \\ Stages of Manufacture of MDF}

Fig. 7 Illustrates the stages of manufacture of MDF, whereas Fig. 8 shows a process chart of the manufacturing operations. 


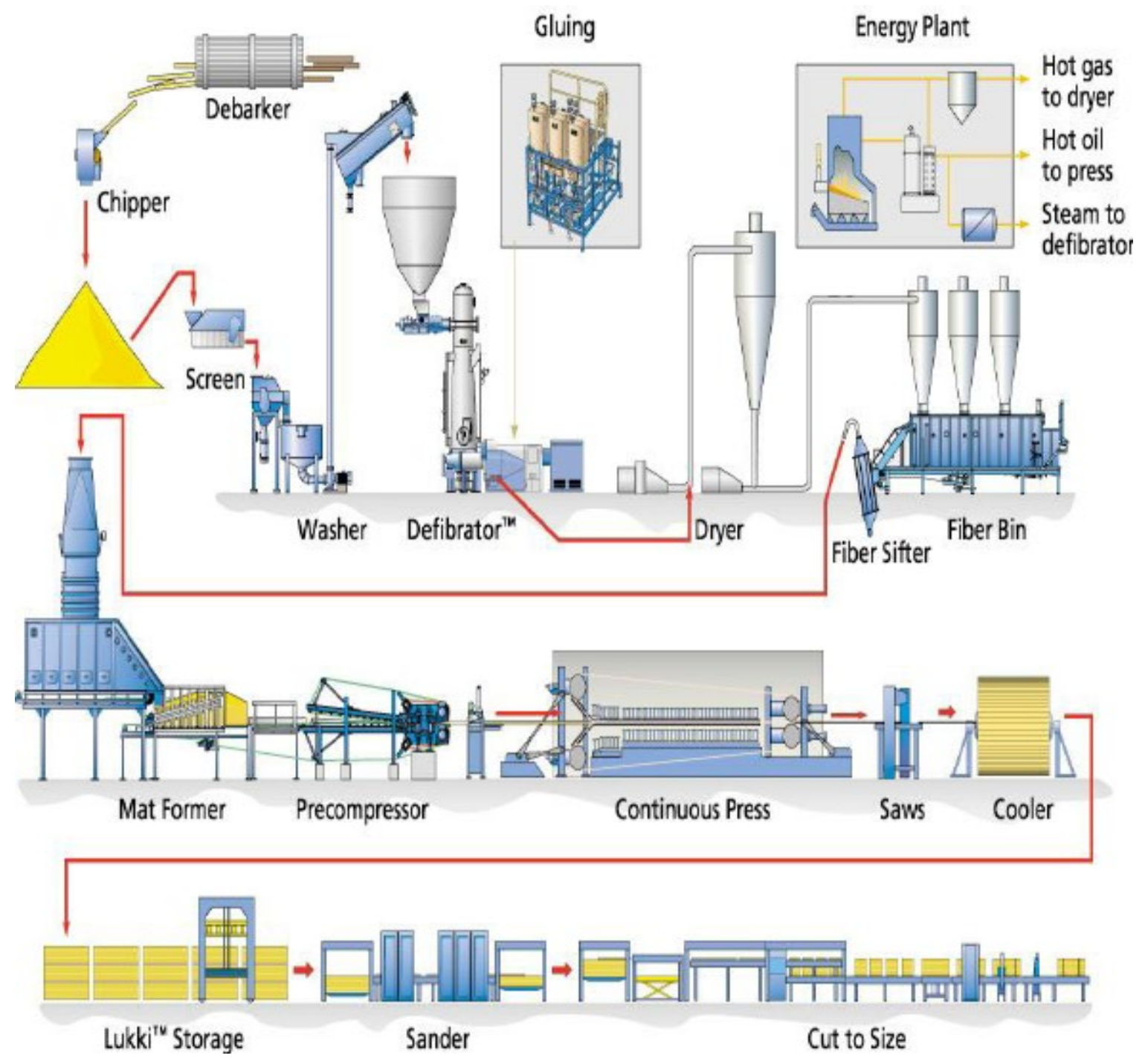

Fig. 7: Stages of manufacture of MDF [3]. 


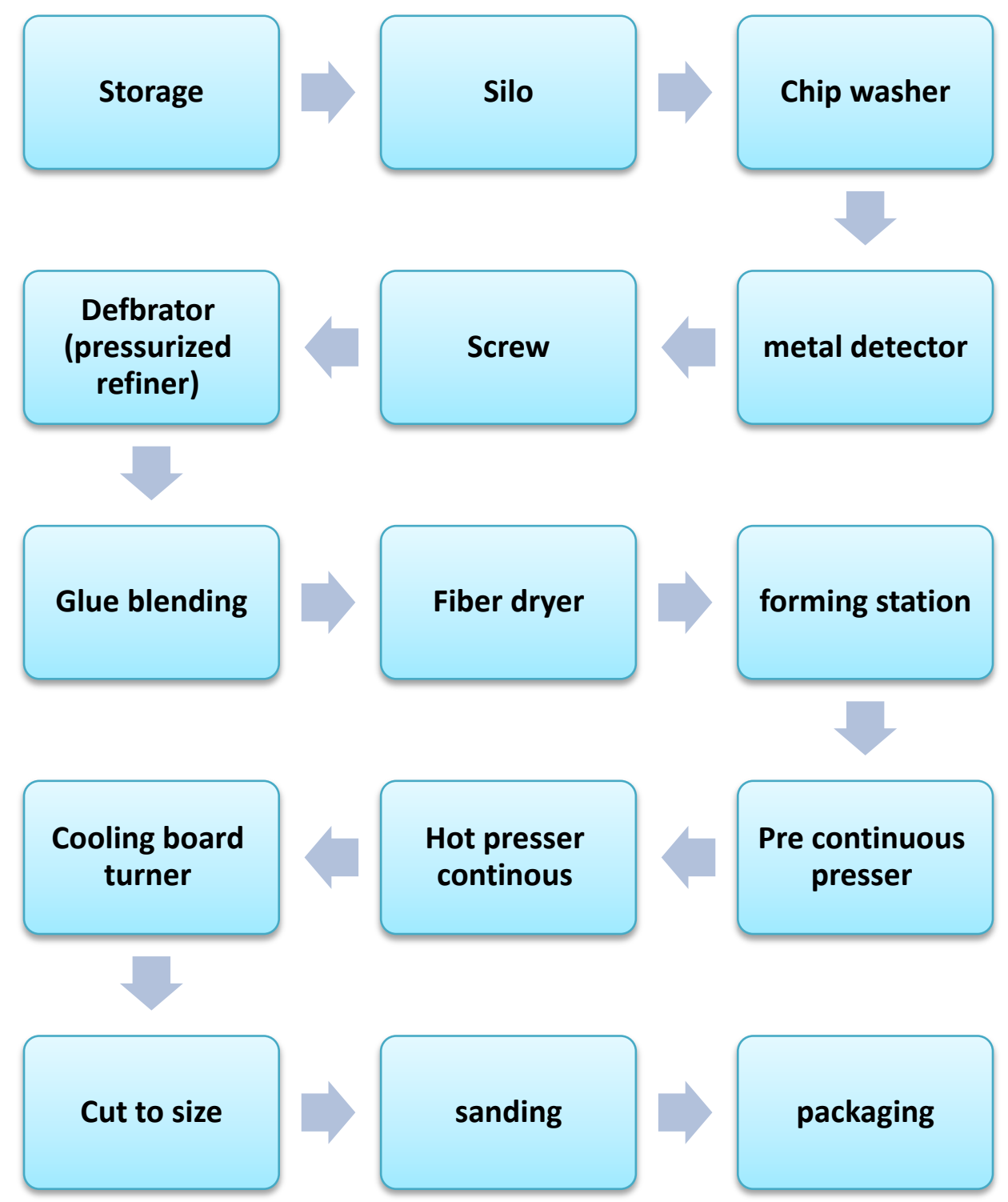

Fig. 8: Flow process chart of the sequence of manufacturing operations of MDF.

\section{Demand Estimates and the Market Gap of Medium Density Fiber Boards in Egypt}

Table (2) shows the demand and local production of MDF from 2016 to 2026. It is known that there is currently only one MDF factory in Naga-Hammadi in Qena governorate (working with bagasse); its expansion in production will not reach more than 97 thousand $\mathrm{m}^{3}$ in 2026.

It is clear that the market gap of MDF in Egypt ranges from $80 \%$ to $90 \%$. This represents a promising opportunity to invest in the MDF industry, based on palm by-products. In addition, local investment in MDF production will reduce the burden on Egypt's balance of payments. 
Table 2: Estimated demand for MDF and the market gap during the period from 2016 to 2026 (thousand cubic meters)

\begin{tabular}{ccccc}
\hline Years & $\begin{array}{c}\text { Demand } \\
\text { estimates }\end{array}$ & $\begin{array}{c}\text { Local } \\
\text { production }\end{array}$ & Market gap & Market gap ratio \\
\hline 2016 & 300 & 30 & 270 & $90 \%$ \\
\hline 2017 & 325 & 65 & 250 & $79 \%$ \\
\hline 2018 & 331 & 97 & 234 & $71 \%$ \\
\hline 2019 & 347 & 97 & 250 & $72 \%$ \\
\hline 2020 & 365 & 97 & 268 & $73 \%$ \\
\hline 2021 & 383 & 97 & 286 & $75 \%$ \\
\hline 2022 & 402 & 97 & 305 & $76 \%$ \\
\hline 2023 & 422 & 97 & 325 & $77 \%$ \\
\hline 2024 & 443 & 97 & 346 & $78 \%$ \\
\hline 2025 & 465 & 97 & 368 & $79 \%$ \\
\hline 2026 & 489 & 97 & 392 & $80 \%$ \\
\hline
\end{tabular}

\section{Results of the Financial Study of the Project}

\section{Net Annual Revenue}

According to estimates of the annual revenues of the project for the construction of a MDF plant operating with palm by-products in E--Bahariah oases as well as annual operating expenses; according to the 2015 estimates, the project achieves net pre-tax revenues of about LE 33.4 million annually, which has an annual average of 22.5\% (in accordance with the Egyptian tax system at the time of conduction of study: 2016); the net after-tax income of the project (table 3) is estimated at LE 25.9 million per year.

Table 3: Net annual revenue of MDF panel production project

\begin{tabular}{ccc}
\hline & $\begin{array}{c}\text { Value (million } \\
\text { pounds) }\end{array}$ & $\begin{array}{c}\text { Relative importance } \\
(\%)\end{array}$ \\
\hline Project income & 82.3 & $100 \%$ \\
\hline Operating expenses & 48.8 & $59.4 \%$ \\
\hline Net profit before tax & 33.4 & $40.6 \%$ \\
\hline Tax payable & 7.5 & $9.1 \%$ \\
\hline Net profit after tax & 25.9 & $31.5 \%$ \\
\hline
\end{tabular}




\section{Profitability Indicators}

The financial feasibility study for the project of MDF production using palm by-products in the El-Bahariah oases is discussed below. The following are a set of indicators to guide the feasibility of the project, as shown in Table 4:

Table 4: Profitability indicators for MDF production project

\begin{tabular}{c|c|}
\hline The project profitability & Value of the indicator \\
\hline Return rate on invested capital & $39.4 \%$ \\
\hline Revenue/rate: costs & $1: 1.43$ \\
\hline Payback period & 3.6 Year \\
\hline Net present value & 92.9 \\
\hline Internal rate of return & $36.2 \%$ \\
\hline
\end{tabular}

Result of Testing of Samples of MDF Manufactured from Palm Products of Pruning

Samples of products of pruning of date palms have been sent from El-Bahariah oases to the laboratories of Naga-Hammadi Company for Fiber boards. The quantities of palm midribs, palm leaflets, spadix stems, coir and palm midrib ends were proportional to the real masses of these products per palm. Appendix (1) illustrates the results of testing of the MDF specimens. The results of test are as follows:

\section{Physical and chemical properties}

- Humidity (5.2\%, which falls within the limits $4-11 \%$ of EN 322).

- Water absorption (12.7\%, which is less than the corresponding value of $15 \%$ in EN 317).

- Formalin emission (22.54 mg/100 mg, which is less than the corresponding value $30 \mathrm{mg} / 100 \mathrm{mg}$ in EN 120).

\section{Mechanical properties}

- Modulus of rupture $\left(24.4 \mathrm{~N} / \mathrm{mm}^{2}\right.$, which is higher than the corresponding value $20 \mathrm{~N} / \mathrm{mm}^{2}$ in EN 310:)

- Modulus of elasticity ( $2911 \mathrm{~N} / \mathrm{mm}^{2}$, which is higher than the corresponding value 2200 $\mathrm{N} / \mathrm{mm}^{2}$ in EN 310)

- Internal bond $\left(0.9 \mathrm{Nmm}^{2}\right.$, which is much higher than the corresponding value $0.55 \mathrm{~N} / \mathrm{mm}^{2}$ in EN 319)

- Surface strength (1.35 N, which is higher than the corresponding value $1.2 \mathrm{~N}$ in EN 311)

All previous profit indicators for the MDF production from palm by-products in El-Bahariah oases reflect, according to the 2016 estimates, high financial returns and economic viability.

\section{Conclusion}

The establishment of MDF projects in Egypt, as well as in countries having extensive date palm plantations, have good economic returns. In addition, the economic success of these projects will increase the added value of date palm plantations, which provides a stimulus for the augmentation of planting of date palms in Egypt and the whole Arab region. In addition, there are several developmental returns: providing labor opportunities in rural and urban areas, building of endogenous scientific and technological capabilities and the improvement of the 
balance of payments via substituting a portion of imported wood products by local MDF production.

\section{References}

$$
\begin{aligned}
& \text { [1] حامد إبر اهيم الموصلي، در اسة عن استخدام البو اقي الزر اعية بمنطقة الثرق الادنى في تحقيق التنمية المستدامة، منظمة }
\end{aligned}
$$

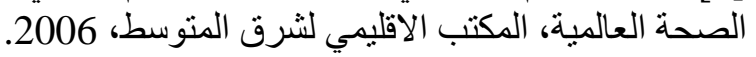

$$
\begin{aligned}
& \text { [2] حامد إبر اهيم الموصلي، مشروع تحسين الاوضاع البينية ور عاية النخيل و الاستخدام الاقتصادي لمنتجاتة الثانوية في }
\end{aligned}
$$

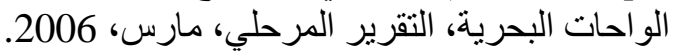

$$
\begin{aligned}
& \text { [3] حامد إبر اهيم الموصلي، مشروع تحسين الاوضاع البينية ور عاية النخيل و الاستخدام الاقتصادي لمنتجاتة الثانوية في } \\
& \text { الواحات البحرية، والتقرير النهائي، يونيو } 2016 . \\
& \text { [4] وزارة الزر اعة و استصلاح الار اضي، قطاع الثؤن الاقتصادية، الادارة المركزية للاقتصاد الزر اعي، نشرة الاقتصاد } \\
& \text { الزر اعي، } 2015 . \\
& \text { [5] سعود عبد الكريم الفذا ،رمزي عبد الرحيم ابو عيانه، المنتجات الثانوية للنخيل، اوقاف الر اجحي، } 2017 .
\end{aligned}
$$

[6] Central Agency for Mobilization and Statistics, USDA, Foreign Agriculture Service, Global Agriculture Information Network, Egypt, wood sector Report, 29/9/2015.

[7] Egypt wood sector report, USDA Foreign Agriculture Service, 2015.

[8] UNECE/FAO Timber data base, July 2018.

[9] United National Data, 2018.

[10] WTO and CAPMAS: 2000-2016 Central Agency for Mobilization and Statistics.

[11] Information on http://www.masress.com.

[12] Information on http://www.ahram.org.eg/Index.aspx.

[13] Information on https://www.nmisr.com.

[14] Information on https://www.alnharegypt.com.

[15] Information on http://hanooon.yoo7.com.

[16] Information on http://elbashayeronline.com.

[17] Information on https://alwafd.org.

[18] Information on http://www.almalnews.com/Default.aspx.

[19] Information on http://live-match-stream-online.blogspot.com.eg.

[20] Information on http://prices.hooxs.com/contact. 
Appendix (1):

Results of tests of samples of MDF, manufactured from the products of pruning of date palms in El-Bahariah oases

The tests have been conducted in the laboratories of Naga-Hamadi Fiberboards Company. 


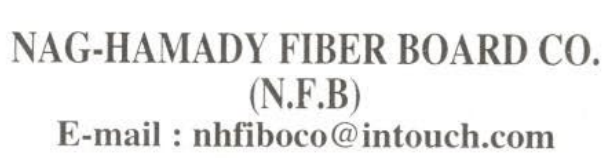

الاختبارات الفيزيائية والميكانيكية لعينات الالواح المصنعة معمليا من المنتجات

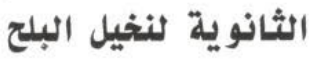

\begin{tabular}{|c|c|c|c|c|c|c|}
\hline \multicolumn{7}{|c|}{ ا- الاختبـار ات الفيز يـائية و الكيميائية } \\
\hline انبعات الفر مـالين & الامتصاص & التشرب & الر طوبة & الكثافة & السمك & الاختبار \\
\hline مجم//..اجم & $\%$ & $\%$ & $\%$ & كجم/קr & مهم & الوحدة \\
\hline Yr, O\& & $0 \wedge, \cdot \varepsilon$ & Ir, $\mathrm{V}$ & $0, r$ & vor,... & $1 \%, \ldots$ & النتيجـة \\
\hline$\cdot, \wedge \vee$ & Y, 0 & $1, r$ & .11 & $r \varepsilon, r \wedge$ & $\cdot, \cdot \varepsilon$ & الانحر اف المعياري \\
\hline EN120 & BS1142 & EN317 & EN322 & EN323 & EN323 & الطريقة القياسية \\
\hline$r \cdot \geq$ & & 10 & $11-\varepsilon$ & -- & - & المواصفات القياسية \\
\hline
\end{tabular}

r- الاختبيار ات الميكانيكية

\begin{tabular}{|c|c|c|c|c|c|}
\hline $\begin{array}{l}\text { قوة شد السطح } \text { Surface } \\
\text { soundness }\end{array}$ & $\begin{array}{c}\text { الر ابطة الداخلية } \\
\text { IB }\end{array}$ & $\begin{array}{l}\text { معامل } \\
\text { MOE }\end{array}$ & معامل الكسر & السمك & الاختبار \\
\hline نيو تن & نيوتن/مهمب & نيو تن/مهم & نيوتن/مهم & مهم & الوحدة \\
\hline 1, ro & $\cdot 9$ & rall & $r \varepsilon, \varepsilon$. & ir & النتيجة \\
\hline$\cdot, r$. & $\cdot, r$ & YA., Or & $r, \varepsilon q$ & $\cdots, \cdot \varepsilon$ & الانحر اف المعياري \\
\hline EN311 & EN319 & EN310 & EN310 & EN323 & الطريقة القياسية \\
\hline $1, r$ & $\cdot, 00$ & rr.. & $r \cdot, \cdots$ & & المو اصفات القياسية \\
\hline
\end{tabular}

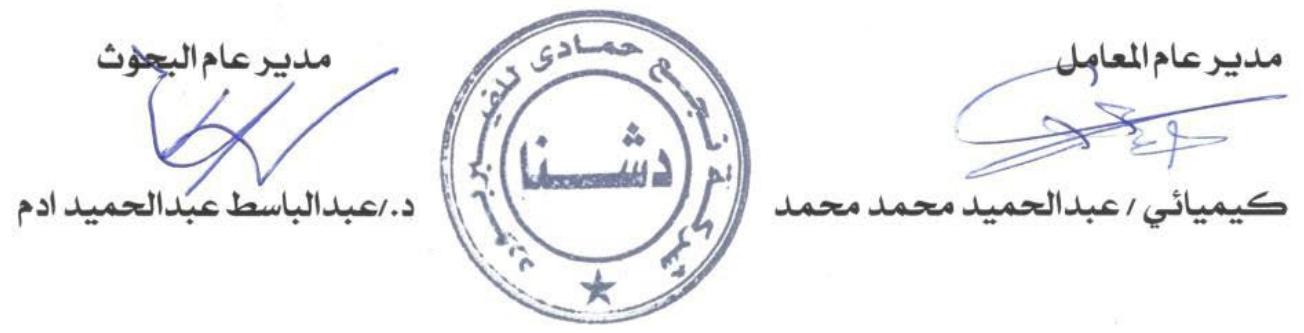

Cairo Office : 17 Gawad Hosni St., Cairo - Egypt

Tel.: $+2 / 02 / 23922109+2 / 02 / 23902995$ Fax: $+2 / 02 / 23926511$

P.O.Box : 432 Mohamed Farid

Factory : Desna - Qena

Tel.: +2/096/6743281 - +2/096/6743002 Fax : +2/096/6743003

website : www.geocities.com/nhfiboco/company-profile html

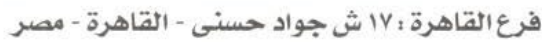

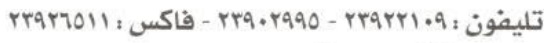

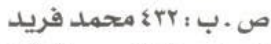

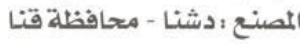

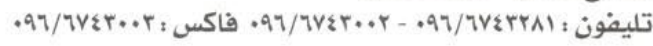

